weeks. They ate every morsel of bark off the trunk and branches, and then cut off the boughs, gnawed them into lengths, and took them to the dam and to their "lodge." The latter began as a burrow in the bank. As they gradually enlarged this, and filled up the bottom with wood chips, they broke open the roof to get head room, and constantly added to the dome with mud and sticks. It is now a large untidy mound on the bank, which at this point is steep.

The process described above accounts partly for the evolution of the beaver lodge from the burrow. But the keeper of Lord Bute's beavers stated that the beavers at Rothesay did clean out the old shavings which they took in to make beds of, and plastered them on the outside of their lodge, or on the same embankment. The present writer inclines to believe that this is likely to be correct, not in every case, but in some, for it is very much in keeping with beaver character. In such cases he ventures to offer the following solution of the growth of the lodge, in cases where the beavers remove their bedding of chips. The water above the dam, owing to the causes mentioned above, rises higher yearly. This must also raise the level in the sub-aqueous passage leading to the beavers' chamber, and in time tend to invade the chamber itself. To remedy this the beavers would naturally raise the floor, and leave the débris of old "beds" on it, piling fresh stuff on the top, and at the same time quarry out the roof, both for head-room and to get fresh earth for their floor. When once the artificial roof was made the same process would go on, until the rising water flooded out the floor altogether, and surrounded the lodge, as one sees it in old Canadian pictures. The lodge would thus take the beehive, moated, form which it has in those conventional plates, even though it lacks the windows which the French artists added for effect. The beavers occasionally escape by burrowing under the corrugated iron fence. This is not always intentional on their part, and they are easily caught again. IVhencver one gets out it travels up the stream, visiting the pools above. There a box-trap is set next night, baited with dog-biscuit, of which the beavers are fond, and the animal is certain to be caught. One beaver, out for a stroll like this, tried to cut down a large Scotch fir, and did cut down a silver birch. The first indication to the keeper next morning that a beaver had escaped was the sight of this tree, in full leaf, lying across a path.

We mentioned above that the Leonardslee beavers had not made either a canal or a rolling path. There is no need for either; for there are no more trees to cut down, or logs to roll from a distance. But it is worth devoting a few lines to these, two of the less known, but not least extraordinary exhibitions of beaver intelligence. An old-established colony soon clears off all the timber near its home. In order to convey the more distant logs to the dam they carefully clear paths, and roll the battens of wood down to the water. But the beaver canal, to which proper attention was first drawn by Mr. Lewis Morgan, is, in the writer's opinion, more wonderful still. It is nothing more nor less than a waterway, or several waterways cut from points on the stream to such parts of the adjacent plantations or woods as the beavers wish to visit, or cut timber in. Sometimes, also, it is made through the centre of an island, to make short communication by water. To this canal the beavers roll their logs, and then tow them to their dam. It has been urged that these canals are accidental, merely worn out along the customary roads; some are, no doubt. But wherever the writer has scen tame beavers kept, even at the London Zoo, he has seen them at different times cut trenches to the edge of their pool, though as that at the Zoo was surrounded by a stone rim, the beavers could not fill the trench with water. Of course, there this trench was only a few feet long. But it is quite clear that Lord Bute's beavers,

$$
\text { NO. } 1467 \text {, VOL. } 57]
$$

which had a considerable area in which to cut their timber, tried to dig canals. This is the description given by their keeper, who, though well acquainted with beaver stories, evidently had never heard of the canal. "Their burrows they make by cutting a road from the middle of the dam for several yards into the dry ground, where they scoop out a dome-shaped burrow... . Some of the roads to these burrows are from fifteen to twenty yards long, and so level that the water follow's them in the ailhole length"! Here is, undoubtedly, an instance of the beaver canal.

Those who care to compare the methods of the Canadian beavers acclimatised at Leonardslee with the works and ways of the European beavers still surviving in Norway, will find an interesting account of the past and present history of the Norwegian beaver, by Mr. R. Collett ("Bieveren i Norge"), 1 illustrated with twelve plates of beaver lodges and dams, and supplemented by an English summary.

The beavers' present range is confined to the Stifts of Christiania and Christiansand, but a few remain on Bratsberg Amt and Stavanger Amt. The larger colony is on the River Nisser (or Nid), the westernmost colonies beins on the river Mandal. In all cases they fecd not on fir, but on deciduous trees, mainly the aspen. When not on the banks of large rivers they make dams, one of which, near Hellersli (Trungen), was built entirely in three weeks, and formed a lakelet more than 100 yards across. The length of the dam was 14 metres. In only one respect do the habits of the Norway beavers differ from those of the Canadian species. Those that live on the banks of the large rivers cannot make a dam over such rapid and deep waters. Yet these rivers rise and fall, and there is a danger of the lodge being either flooded or left high and dry. In these places the beavers build long lodges, at right angles to the stream, and sloping up the bank. When the river rises, the beaver can go up to the higher end of his lodge ; when it falls, the entrance is still submerged and safe.

In I 880 Mr. Cocks estimated the number of beavers surviving in Norway at 60 ; in I $883 \mathrm{Mr}$. Collett believes there were 100 . Since 1894 and I 895 the beavers have been protected by law in their two principal haunts, for a period of ten years in each district.

\section{J. CORNish,}

\section{SCIENTIFIC INVESTIGATIONS OF THE LOCAL GOVERNIIENT BOARD:-}

THE Annual Reports of the Medical Officer of the Local Government Board constitute in many respects the best treatise on practical hygiene we possess. Their diligent perusal by the embryo health officer would equip him as no ordinary text-book can do for the intelligent discharge of his duties. It would be well if candidates for Public Health degrees were examined upon the salient features of these reports. The volume for $189 j-96$, which has just been issued, contains certain features of interest. There is the usual admirable summary of the year's work by Sir Richard Thorne; statistics with regard to vaccination, and a compilation of returns of notified infectious diseases in urban districts and in the county of London. Valuable reports are also contributed by Dr. Copeman and Dr. Buchanan upon outbreaks of enteric fever, and by Dr. Sweetings upon an outbreak of diphtheria. The able report by the late Mr. R. W. Thomson upon the sewerage and drainage arrangements of certain valleys in the counties of Monmouth and Glamorgan, leads one to join in the regret expressed at the loss of this talented official. It is, how-

1 Eergen : Grieg's " Bogtrykheri." 2 Twenty-fifth Annual Report of the Medical Officer of the Locas.
Government Board, $1895-96$. 
ever, the auxiliary scientific investigations which call for more special notice in these columns.

The several cases of Asiatic cholera that occurred in this country during i $\$ 93$, led the Local Government Board to keep a diligent watch in the subsequent year over any cases that presented symptoms of a choleraic nature, and Dr. Klein gives an account of the bacteriological examination made by him in twenty-nine instances. The comma bacillus was not found in any of the cases; they therefore proved to be examples of cholern nostras, or English cholera. This conclusion is a further confirmation, if that were needed, of the diagnostic value of Koch's methods. When Dr. Klein says, "if the vibrio of Koch could be demonstrated in the bodies of persons not connected in any way with the cholera localities of 1893 , the bacteriological test as an important help in distinguishing between Asiatic cholera and cholera nostras would become practically worthless," he is surely suggesting a doubt that does not exist amongst the great mass of observers. In a number of the cases the bacillus coli was found to be the predominant micro-organism. Of fresher interest is Dr. Klein's description of an organism isolated from cases of diarrhcal illness due to the consumption of milk, and named by him, "Bacillus enteritidis sporogenes." There is a nisleading sentence on p. 196: "ordinary milk, such as is bought in many a shop in London, contains as a rule an abundance of bacillus coli, and if put aside it will rapidly 'sour' and coagulate spontaneously owing to the multiplication of bacillus coli." This might lead most readers to assume that the ordinary "souring" of milk is due to bacillus coli, and not, as is the case, to one or other of a considerable number of lactic acid producing organisms. Dr. Klein proceeds to a further report on prophylaxis in diphtheria, in which are mainly detailed the results of injecting living diphtheria cultures into the horse with the view of obtaining antimicrobic substances in the blood. The experiments do not appear to have brought out results of practical value, either with his own "antimicrobic" serum, or with antitoxic serums obtained from various sources. Dr. Klein also contributes a "Further Report upon Protective Inoculations" which will be read by all interested in the subject of which it treats.

"Snake venom in its prophylactic relations with poison' of the same and of other sorts," is the subject of a lengthy communication by Dr. Kanthack. The work of Calmette and others upon the effect of cobra antitoxic serum upon the poison of snakes other than the cobra is discussed, and there follow observations upon the nature of the immunity of certain snakes to certain snake poisons. Dr. Kanthack has not been able to confirm Calmette's statement, that the injection of solutions of chlorinated lime have value as a curative or immunising agent. On the other hand, as Calmette states, an antitoxic serum can be produced in rabbits by administration of the cobra poison itself, and still better results are obtained by using the mixture of venom and chlorinated calcium. The inhibitory influence of different antitoxic serums upon cobra venom is next dealt with. The experimental data given are in many respects incomplete, and it would perhaps have been well to wait till the experiments were finished before publishing any conclusions from them.

Dr. Kanthack instances the marked retarding influence of liver extracts on the action of cobra venom. This most interesting statement is supported by three experiments, and their continuation left for a future date. There follow notes on "immunising serum." It is again disappointing to find experiments quoted with the acldendum, "the number of my observations are too limited." Attention should be drawn to an experiment Dr. Kanthack performed on himself with most remarkable results. In the course of nine days Dr. Kanthack swallowed $; \mathrm{I}^{*}+\mathrm{cc}$. of living and dead broth cultures of the cholera vibrio, and a solution of sodic carbonate to neutralise the gastric acidity. A week later blood was obtained from the arm, and $3 \mathrm{cc}$. of the separated blood serum was injected into each of three guinea-pigs intraperitoneally. Four days later the guinea-pigs were respectively inoculated with $B$. prodigiosus, B. pyocyaneus and $V$. cholerce-only the guinea-pig inoculated with cholera remained alive. The immunisation Dr. Kanthack had effected on himself per os, was apparently transmitted by means of his blood serum to the guinea-pig.

The paper concludes with notes upon Pfeiffer's, Bordet's, and Durham's tests for the cholera and typhoid organisms. It would have rendered the description clearer in one or two instances if it had been explained what actually was seen, instead of expressing the results as "not quite negative" and "did not react absolutely negatively:" Dr. Kanthack considers that "a general conclusion at this stage as to the specificity of antitoxic or immunising serum would be premature," though the facts so far obtained tend to support this conclusion. The paper is one more adapted for perusal by specialists intimately acquainted with the subject than by the general reader, who might be apt to carry away false notions as to the finality of a number of the results ob. tained. One cannot resist the impression that the material for half a dozen researches has been crowded into the space of one paper.

The difficult subject of food poisons is considered from the bacteriological aspect by Dr. Cautley. The object of the inquiry was to ascertain whether the multiplication or pathogenic propertics of bacteria normally present in the digestive tract, viz. B. coli and Proteus vulgaris, are influenced by association with the non-pathogenic organisms to be commonly met with in food. Dr. Cautley was able to demonstrate that the virulence of the above bacilli is increased by simultaneous injection with certain food organisms into animals. On the other hand, feeding experiments on similar lines gave negative results. Dr. Monckton Copeman and Dr. Blaxall contribute reports on the advantages of glycerinated vaccine lymph. The volume, like its predecessors, contains much of interest and value to sanitarians and bacteriologists.

THE ARCTIC WORK OF MR. R. E. PEARY.

ON Monday evening Mr. R. E. Peary, U.S.N., presented to the Royal Geographical Society a statement of the results of his Arctic explorations and of his plans for continuing these.

Mr. Peary has been engaged in exploring Northern Greenland for the greater part of the last ten years, and in the course of his sledge journeys he has had more opportunities of studying the inland ice than has fallen to the lot of any other explorer. The most remarkable journey of the series was that of $1 \delta 92$, when he crossed the ice-cap from Inglefield Gulf and discovered Independence Bay on the north-east coast of Greenland. This journey showed that the inland ice terminated to the north, and that there was no road that way to the pole. Land was seen to the northward, which MIr. Peary believes to be separated by a channel from Greenland, and to extend probably some distance beyond the furthest north attained by Lockwood on Greely's expedition, $83^{\circ} 24^{\prime}$. A second journey to Independence Bay in IS93 was frustrated by the unexampled severity of the weather; the party, which started with forty-two dogs returned with only one. In $1 \$ 95$ another attempt was more successful, but the resources of the expedition and the transport avallable were insufficient to allow any advance beyond the position of 1892.

After this journey Mr. Peary resolved to wait until the

No. $[467$, voL. 57$]$ 